\title{
Energy and exergy analysis of alternating injection of oxygen and steam in the low emission underground gasification of deep thin coal
}

\author{
Eftekhari, Ali Akbar; Wolf, Karl Heinz; Rogut, Jan; Bruining, Hans
}

Published in:

Applied Energy

Link to article, DOI:

10.1016/j.apenergy.2017.10.063

Publication date:

2017

Document Version

Publisher's PDF, also known as Version of record

Link back to DTU Orbit

\section{Citation (APA):}

Eftekhari, A. A., Wolf, K. H., Rogut, J., \& Bruining, H. (2017). Energy and exergy analysis of alternating injection of oxygen and steam in the low emission underground gasification of deep thin coal. Applied Energy, 208, 6271. https://doi.org/10.1016/i.apenergy.2017.10.063

\section{General rights}

Copyright and moral rights for the publications made accessible in the public portal are retained by the authors and/or other copyright owners and it is a condition of accessing publications that users recognise and abide by the legal requirements associated with these rights.

- Users may download and print one copy of any publication from the public portal for the purpose of private study or research.

- You may not further distribute the material or use it for any profit-making activity or commercial gain

- You may freely distribute the URL identifying the publication in the public portal 


\title{
Energy and exergy analysis of alternating injection of oxygen and steam in the low emission underground gasification of deep thin coal
}

\author{
Ali Akbar Eftekhari ${ }^{\mathrm{a}, *, 1}$, Karl Heinz Wolf ${ }^{\mathrm{b}}$, Jan Rogut ${ }^{\mathrm{c}}$, Hans Bruining ${ }^{\mathrm{b}}$ \\ a Centre for Oil and Gas, Technical University of Denmark, Building 375, 2800 Kgs. Lyngby, Denmark \\ b Section of Geo-environmental Engineering, Department of Geotechnology, Faculty of Civil Engineering and Geo-sciences, Delft University of Technology, Stevinweg 1 , \\ 2628 CN Delft, The Netherlands \\ c Główny Instytut Górnictwa (Central Mining Institute), Plac Gwarków 1, 40-166 Katowice, Poland
}

\section{H I G H L I G H T S}

- We model UCG process with alternating injection of steam/oxygen.

- We used exergy analysis to investigate the practicality of the process.

- We show that the alternating injection UCG is practical at low pressure.

- Zero emission conversion of coal is not currently practical.

- Co-injection of steam/oxygen results in a higher recovery of coal.

\section{A R T I C L E I N F O}

\section{Keywords:}

Underground coal gasification

Alternating injection

Exergy analysis

Carbon capture and storage

\begin{abstract}
A B S T R A C T
Recent studies have shown that by coupling the underground coal gasification (UCG) with the carbon capture and storage (CCS), the coal energy can be economically extracted with a low carbon footprint. To investigate the effect of UCG and CCS process parameters on the feasibility of the UCG-CCS process, we utilize a validated mathematical model, previously published by the same authors, that can predict the composition of the UCG product, temperature profile, and coal conversion rate for alternating injection of air and steam for unmineable deep thin coal layers. We use the results of the model to conduct an energy and exergy analysis of the UCG process. We study the effect of various process parameters on the efficiency of the UCG process, the zeroemission recovery factor of coal, and the total $\mathrm{CO}_{2}$ emission of the process. Moreover, we compare the alternating injection of air/steam with the injection of an air and steam mixture.

Exergy analysis shows that the alternating injection of air/steam describes a practical process for UCG at low pressure. However, injecting a mixture of steam and oxygen results in a practical recovery factor of coal higher than the alternating injection process. Additionally, we show that the zero-emission conversion of unmineable deep thin coal resources in a coupled UCG-CCS process, that is not practical with the current state of technology, can be realized by increasing the energy efficiency of the carbon dioxide capture process.
\end{abstract}

\section{Introduction}

According to the International Energy Agency, more than $40 \%$ of the global electricity production is from coal power plants [1]. The high carbon content (per unit heating value) of coal compared to other hydrocarbons and its worldwide utilization for electricity production makes coal one of the main contributors to the rising carbon dioxide concentration in the atmosphere. The increased societal concerns regarding the role of carbon dioxide concentration in the global climate change demands a more effective and cleaner utilization of coal. According to Friedmann and coworkers who analyzed the published data of the commercial UCG pilots, a low carbon content fuel can be produced by combining UCG and carbon capture and storage (CCS), with a considerably lower cost compared to the ex-situ surface gasification. The existence of mature $\mathrm{CO}_{2}$ capture technologies for decarbonizing the UCG product stream and the proximity of the potential CCS sites to the coal resources [2] are among the reasons that may potentially lead to an economic UCG-CCS process $[3,4]$. However, Friedmann et al. point out

\footnotetext{
* Corresponding author at: The Research was conducted at Delft University of Technology, The Netherlands.

E-mail addresses: aliak@dtu.dk (A.A. Eftekhari), k.h.a.a.wolf@tudelft.nl (K.H. Wolf), rogutjan@yahoo.com (J. Rogut), j.bruining@tudelft.nl (H. Bruining).

${ }^{1}$ Centre for Oil and Gas, Technical University of Denmark, Electrovej Building 375, 2800 Kgs. Lyngby, Denmark.
} 


$\begin{array}{ll}\text { Nomenclature } \\ C_{\text {fuel }} & \mathrm{CO}_{2} \text { emission }[\mathrm{kg} / \mathrm{J}] \\ \Delta h_{\mathrm{H}_{2} \mathrm{O}}^{\text {va }} & \text { heat of vaporization of water }[\mathrm{J} / \mathrm{mol}] \\ e_{\mathrm{CH}_{4}} & \text { methane emission factor }[\mathrm{kg} / \mathrm{J}] \\ E x_{\text {coal }} & \text { CCS exergy requirement }\left[\mathrm{J} /\left(\mathrm{m}^{2} \mathrm{~s}\right)\right] \\ E x_{\text {comp }} & \text { compression exergy }\left[\mathrm{J} /\left(\mathrm{m}^{2} \mathrm{~s}\right)\right] \\ E x_{\text {net }} & \text { net recovered exergy }\left[\mathrm{J} /\left(\mathrm{m}^{2} \mathrm{~s}\right)\right] \\ E x_{\mathrm{O}_{2}} & \text { oxygen exergy }\left[\mathrm{J} /\left(\mathrm{m}^{2} \mathrm{~s}\right)\right]\end{array}$

$E x_{p} \quad$ exergy of the UCG product $\left[\mathrm{J} /\left(\mathrm{m}^{2} \mathrm{~s}\right)\right]$

$E x_{\text {pump }}$ pumping exergy $\left[\mathrm{J} /\left(\mathrm{m}^{2} \mathrm{~s}\right)\right]$

$E x_{\text {steam }} \quad$ steam exergy $\left[\mathrm{J} /\left(\mathrm{m}^{2} \mathrm{~s}\right)\right]$

$M_{\mathrm{CO}_{2}} \quad \mathrm{CO}_{2}$ molecular weight $[0.044 \mathrm{~kg} / \mathrm{mol}]$

$N_{\mathrm{C}}^{t} \quad$ carbon flux in the product $\left[\mathrm{mol} /\left(\mathrm{m}^{2} \mathrm{~s}\right)\right]$

$\mathrm{R}^{p r} \quad$ practical recovery factor [-]

$\mathrm{R}^{z e} \quad$ zero-emission recovery factor [-] that the coupling of UCG-CCS is not addressed in the existing pilot projects nor in the modeling and simulation studies [3].

Here, we employ the concept of exergy to first investigate whether it is possible to feasibly extract the deep (1000-2000 m) thin (1-3 m) unmineable coal resources that are abundantly found in European countries like Belgium, the Netherlands, Poland, Bulgaria and Great Britain [5]. Secondly, we investigate the possibility of reducing the $\mathrm{CO}_{2}$ emission by coupling the UCG process to CCS.

Recently, several researchers have investigated the clean utilization of coal in the underground coal gasification [6], focusing on the electrical power generation. Prabu and Jayanti [7] proposed a process for coupling UCG with a solid oxide fuel cell (SOFC), combined with CCS. They suggested that the UCG syngas product can be upgraded to a gaseous product with a high hydrogen content, that is fed to a SOFC unit for the electricity production. Their energy analysis showed that the overall efficiency of the UCG-SOFC system is $32 \%$ and the exhaust gas stream from the process contains $95 \% \mathrm{CO}_{2}$ that is ready for compression and sequestration. For the UCG reaction, they used the experimental data of the Hoe Creek field trial [8]; it is the first successful trial for the injection of oxygen/steam mixture as the gasification agent, although the coal seam is located at only $40 \mathrm{~m}$ depth and the gasification is conducted at a low pressure. Nakaten et al. [9] developed a comprehensive techno-economic model that is able to estimate the cost of electricity, energy consumption, and $\mathrm{CO}_{2}$ emission for a coupled UCG-CCS process where the produced syngas is consumed in a combined cycle gas turbine (CCGT) for the electricity production. In the model, they assumed a fixed composition for the UCG syngas product, which is based on the previously reported values for the deep UCG trials. They used their model to study the electricity production from a deep unmineable hard coal deposit in Bulgaria [10], and concluded that the UCG-CCGT-CCS can be a low carbon alternative to the current coal fired electricity production in Bulgaria. By conducting a sensitivity analysis, they showed that the cost of electricity is dependent on the UCG product composition with a variation of up to $9.8 \%$ [11], signifying the importance of the accurate prediction of the UCG product composition.

Moreover, several researchers have investigated the energetic and exergetic efficiency of the UCG process. Blinderman and Anderson [12] studied the data of the $\varepsilon$ UCG process applied to a $10 \mathrm{~m}$ thick coal layer at $140 \mathrm{~m}$ depth in Chinchilla, Australia. They showed that the overall efficiency of the electricity production from the UCG-IGCC (Integrated Gasification Combined Cycle) can reach $43 \%$, which is comparable to a natural gas combined cycle (NGCC). Blinderman et al. [13] used the concept of exergy to maximize the efficiency of the reverse combustion linking (RCL) process; in the RCL process, high pressure air is injected into a low permeable coal layer and the combustion starts at the production well, propagating backwards to the injection well creating a high permeable link between the injection and production wells. Although here we look into a similar backward gasification process, we consider a process where a link is already established between the injection and the production wells. Eftekhari et al. [14] conducted an exergy analysis of underground coal gasification with simultaneous adsorption of carbon dioxide on pulverized calcium oxide and wollastonite. In their analysis they showed that production of calcium oxide is too energy-intensive for the low emission UCG process to be feasible. Moreover, they use a thermodynamic equilibrium model for the gasification process, which is not accurate specially at lower gasification temperatures. Bicer and Dincer [15] studied a novel integrated system, in which the produced syngas from a UCG process is utilized in an IGCC power plant and solid oxide fuel cells is used for electricity generation, with some of the electricity consumed for hydrogen production and the exhaust steam from the IGCC used for the recovery of heavy oil. They used an equilibrium model for the UCG process and the idea is mostly developed for the region of Alberta, Canada.

In summary, we address two main problems that are associated with the existing thermodynamic analyses of the UCG process; first, the simplified chemical equilibrium models that are used for the prediction of the final UCG product are not accurate specially when the process is controlled by kinetics or mass transfer [16]. Secondly, the analyses are mostly conducted for the shallow thick coal seams, where the gasification reactions occur at low pressure. These coal resources, however, are not abundant in, e.g., Europe. The gasification of deep coal seams must be conducted at higher pressures (close to the hydro-static pressure to avoid the water intrusion when the coal resources are connected to aquifers). It is known that high pressures is detrimental to the quality (i.e., heating value) of the UCG product. However, the effect of pressure on the carbon content of the produced syngas and consequently its impact on the exergy balance of the UCG-CCS process is not yet studied.

We address these problems by using a mathematical model that is developed for the gasification of thin deep coal seams and is able to predict the composition of the gaseous product of a UCG process, where air (oxygen) and water (steam) are injected alternately. In this process, the air injection period serves to heat up the coal and the surrounding strata, and the steam injection period serves to produce high quality gas recuperating the heat from the surrounding strata [17-20]. Here, we use the results of the model to perform an energy and exergy analysis on the whole process. Our objective is to find the efficiency of the UCG process in recovering the coal resources. Moreover, we quantify the total $\mathrm{CO}_{2}$ emission of the process per unit heating value of the final products. We investigate the effect of various parameters including the steam to oxygen ratio in the feed stream, the temperature and pressure of the feed stream, and the gasification pressure on the recovery factor of the process and the carbon content of the product and net $\mathrm{CO}_{2}$ emission of the process.

The organization of the paper is as follows: Section 2 gives an overview of the process and the mathematical model. In Section 2.3 the idea of the exergetic efficiency and recovery factor for an energy conversion process is described. The flow diagram and the major energyconsuming units of the overall process are discussed in Section 2.4. Then, we present the results of the model in Section 3 which includes the effect of steam $/ \mathrm{O}_{2}$ ratio on the quality of the UCG product when a mixture of oxygen and steam is injected. In Section 3.2, we perform an exergy analysis on the overall process and calculate the practical and zero-emission recovery factors of coal. Finally, we end with conclusions. 


\section{Mathematical model}

In this section, we first give a short description of our UCG model. Then we clarify the definitions of two important terms that are used in the paper, viz., efficiency and recovery factor. Finally, we describe the mathematical model for the exergy analysis of the UCG process.

\subsection{The model for deep thin coal gasification}

Fig. 1 shows a schematic of a UCG process. Oxygen (or air) and water (or steam) are injected through an injection well into a channel that links the injection and production wells. Near the production well, the reaction between the injected species starts by supplying heat, e.g., by a propane burner. Coal is consumed and converted to $\mathrm{CO}_{2}, \mathrm{CO}$, and $\mathrm{H}_{2}$ with the following main reactions:

$\mathrm{CH}_{a} \mathrm{O}_{b}+\left(1-b+\frac{a}{4}\right) \mathrm{O}_{2} \rightarrow \mathrm{CO}_{2}+\frac{a}{2} \mathrm{H}_{2} \mathrm{O}$.

$\mathrm{CH}_{a} \mathrm{O}_{b}(s)+(1-b) \mathrm{CO}_{2} \rightleftharpoons(2-b) \mathrm{CO}+\frac{a}{2} \mathrm{H}_{2}$,

$\mathrm{CH}_{a} \mathrm{O}_{b}+(1-b) \mathrm{H}_{2} \mathrm{O} \rightleftharpoons \mathrm{CO}+\left(1-b+\frac{a}{2}\right) \mathrm{H}_{2}$.

Small amounts of other gaseous species, e.g., $\mathrm{SO}_{2}$ have a negligible influence on the heating value of the final product and are thus not considered $[14,16]$. Note that the formation of methane due to the pyrolysis of coal (in the absence of oxygen), as observed previously [21-24], can considerably increase the heating value of the UCG product. However, since the produced gas from the coal pyrolysis is in contact with the injected oxygen from the rubble zone, it is instantly converted to $\mathrm{CO}_{2}$ and $\mathrm{H}_{2} \mathrm{O}$ (see Fig. 2). The heat of combustion is later consumed in the endothermic gasification reactions between the hot gases and the coal surface. For a deep thin coal layer, which is common in Europe, the rapid consumption of coal creates a cavity that is confined by the rock on top and bottom and by coal layers on the other sides. Depending on the geomechanical properties of the roof rock, the expansion of this cavity results in three different scenarios, i.e., no collapse, partial collapse, or complete collapse of the roof. The partial collapse is plausible for a roof that contains "carbonaceous clay, shales, and a mixture of shale and siltstone" $[25,26,16]$. The partial collapse of the roof, as shown in Fig. $2 \mathrm{~d}$ creates two open channels confined by a rubble face, the roof rock, and the coal face. The injected gases which enter from the rubble side, immediately react with the combustible gases $\left(\mathrm{H}_{2}\right.$ and $\left.\mathrm{CO}\right)$. These exothermic reactions creates heat that increases the temperature of the rubble face. The generated heat is transferred to the roof rock, where heat is stored and to the coal face, where the heat is consumed in the endothermic gasification reactions between the hot gases and the coal face. Moreover, the temperature difference between the faces causes a difference in the gas density that enhances the circulation of the gas in the cavity by natural convection. We have reported the mathematical details and the numerical solutions of the model in a previous publication [16]. Here, we use the model to study the effect of various parameters on the heating value and the carbon content of the gasification product, which are necessary for conducting an exergy anlysis of the whole process.

\subsection{Model validation}

We compare the results of the model to a field trial that is performed in a georeactor, shown schematically in Fig. $3[16,18]$. The size of the coal block is $2.4 \times 0.6 \times 0.55 \mathrm{~m}^{3}$ (length $\times$ height $\times$ width) [19]. The injection channel is $2.4 \mathrm{~m}$ long and is at the bottom of the coal seam with a square cross section of $0.07 \times 0.07 \mathrm{~m}^{2}$. Initially, the reaction starts by injecting oxygen for $10 \mathrm{~h}$ and heating up the coal using a propane burner. Then, oxygen and steam are injected alternately in 1.5-2.0 h intervals. We use the same coal composition and injection rate in our model and compare the average composition of the product gas and the temperature profile that are reported by [18] with the results of our model. The results are reported in Table 1 [16]. We can draw the following conclusion from Table 1:

- In the steam injection cycle, which is the cycle that produces the most valuable product, our model is in excellent agreement with the field data, with the exception of $\mathrm{CH}_{4}$ concentration. Given the low reaction rate of methane formation, the $10 \%$ methane composition that is reported by [18] is probably a result of coal pyrolysis that is included in our model but not considered in the simulations (we assumed that the composition of the coal before and after pyrolysis are the same)

- The total carbon content and the hydrogen composition of the product during the oxygen injection cycle are in agreement with the field data. However, the carbon monoxide composition and the final temperature of the coal surface are both overestimated by our model. This is probably due to the fact that in our model, heat is only lost to the roof which is later recuperated when the roof collapses in the form of hot rubble. But in the georeactor, there is no roof collapse and the heat that is generated by the combustion of coal is lost to the surrounding strata. This leads to the observation of a lower temperature during the oxygen injection cycle, which in turn reduces the concentration of $\mathrm{CO}$ that is produced by the endothermic reaction, Eq. (2).

Considering all the uncertainties in the modeling of the complex UCG process and in spite of few discrepancies, our model grasps the qualitative features of the oxygen injection cycle and the quantitative features of the steam injection cycle in the alternating injection of oxygen and steam.

\subsection{Efficiency and recovery factors}

Every process that is designed for the extraction of an energy resource $\left(E_{\text {resource }}\right)$, here an underground coal layer that is shown by a gray circle in Fig. 4 , requires a certain amount of energy $\left(E_{\text {extraction }}\right)$, shown by a white rectangle (Fig. 4). During the extraction process, part of the produced energy is converted to undesirable product $\left(E_{\text {waste }}\right)$, shown by a white circle, and some energy is required to abate the environmental footprint of the process ( $E_{\text {abatement }}$, black ellipse in Fig. 4). The efficiency factor $(\eta)$ of the process that is described above and depicted in Fig. 4c is traditionally defined by the quotient of the useful output and the total input, i.e,

$\eta=\frac{E_{\text {resource }}-E_{\text {waste }}}{E_{\text {resource }}+E_{\text {extraction }}+E_{\text {abatement }}}$.

The main issue with this definition is that no matter how much energy is consumed for the extraction of an energy resource and cleaning its environmental footprint, the efficiency factor is always positive. One

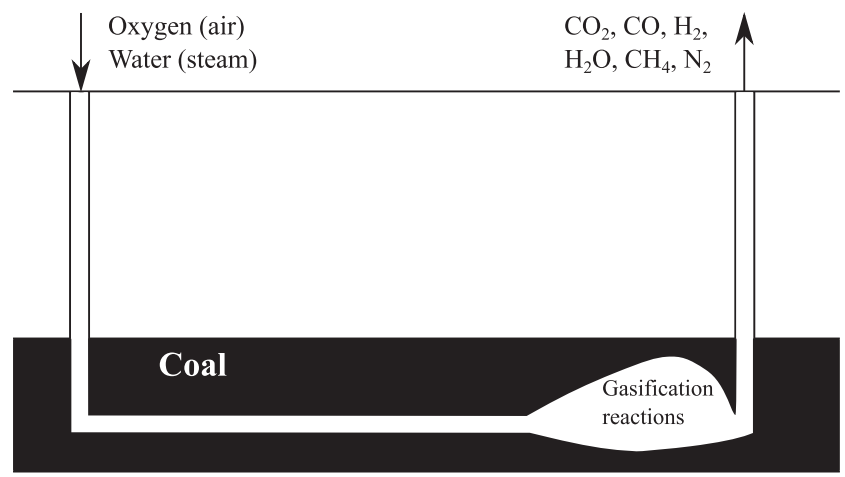

Fig. 1. An schematic diagram of the UCG process. 


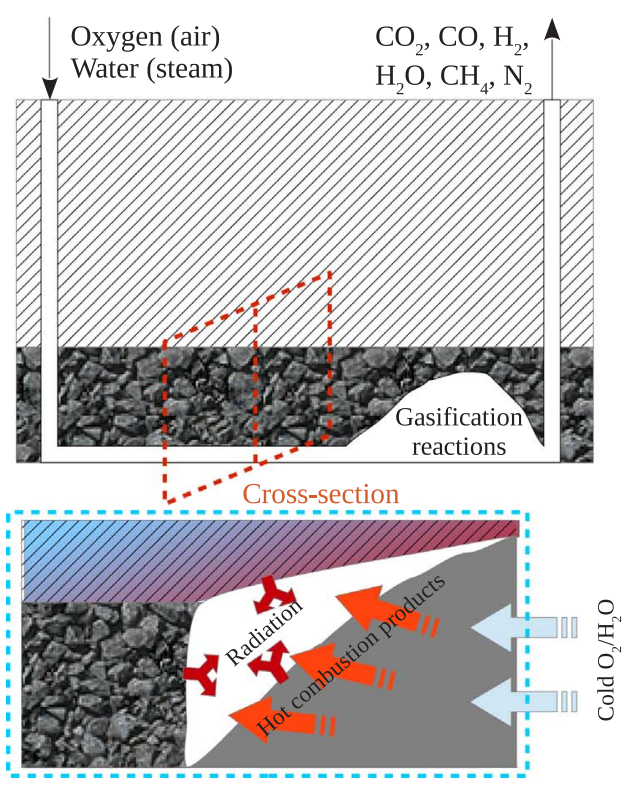

(a)

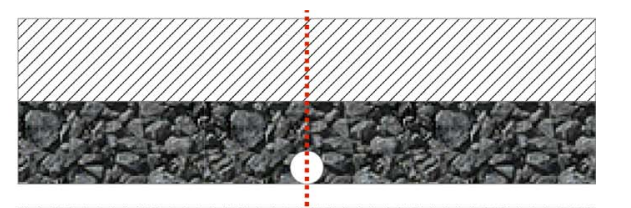

(b)

(c)

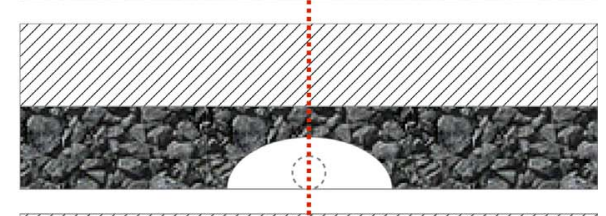

(d)

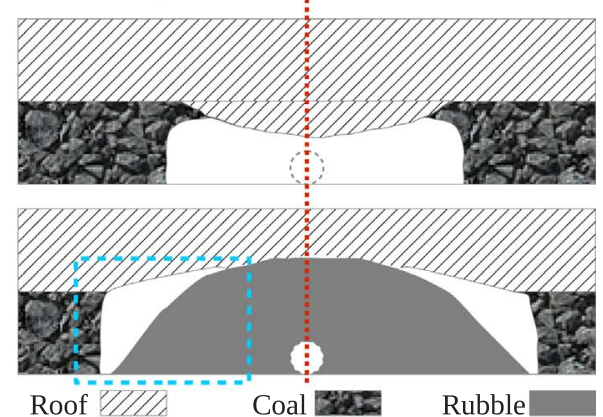

Fig. 2. Schematic flow diagram of underground coal gasification (top left), the cavity growth and partial roof collapse in a cross section perpendicular to the injection line (right), and the convective and radiative heat fluxes in the cavity (bottom left) [16]. can easily see that this definition can be misleading, specially in cases where the energy consumed for the extraction and abatement surpasses the amount of the extracted energy. Hence, for an energy conversion process, we define a recovery factor, i.e.,

$\mathrm{R}=\frac{E_{\text {resource }}-E_{\text {waste }}-E_{\text {extraction }}-E_{\text {abatement }}}{E_{\text {resource }}}$,

that does not have the limitations of the efficiency factor. This concept is shown graphically in Fig. 4b, where the recovery factor is the fraction of the gray area that is not covered by the extraction, abatement, and wasted energy. In the next section, we use this definition to quantify the effect of process parameters on the recovery factor of underground coal gasification process.

We must point out that the above definition is previously discussed and used, in different formats, by several researchers, e.g., [27-30]

\subsection{Process flow diagram}

Fig. 5 shows the process flow diagram of the UCG process. Water is pumped to a steam generator by a centrifugal pump with a mechanical efficiency of $80 \%$ and is converted to high pressure superheated steam. We assume that the steam generator works at a pressure of 10 bar above the injection pressure. The fuel for the steam generator is methane and we disregard the heat loss of the steam generation process. However, considering the length of the injection well and the volumetric flow rate of the steam, we assume a $30 \%$ heat loss in the injection well for the high pressure ( $80 \mathrm{bar}, 800 \mathrm{~m}$ deep) UCG and $10 \%$ heat loss for the low pressure (3 bar, $30 \mathrm{~m}$ deep) UCG [31]. High pressure superheated steam
Table 1

A comparison between the results of our model and the GIG field trial data (the numbers are directly reported from [18], even though some of the compositions do not add up to $100 \%)$.

\begin{tabular}{|c|c|c|c|c|c|c|c|c|}
\hline \multirow[t]{2}{*}{ Period } & \multirow{2}{*}{$\begin{array}{c}\text { Time } \\
\text { interval }[\mathrm{h}]\end{array}$} & \multirow[t]{2}{*}{ Results } & \multicolumn{4}{|c|}{ Composition (mol\%) } & \multicolumn{2}{|c|}{$\mathrm{T}[\mathrm{K}]$} \\
\hline & & & $\mathrm{CO}_{2}$ & $\mathrm{CO}$ & $\mathrm{H}_{2}$ & $\mathrm{CH}_{4}$ & Start & End \\
\hline \multirow[t]{2}{*}{ Initiation } & $1-10$ & GIG & 25 & 36 & 33 & 2 & 308 & 1300 \\
\hline & & Model & 35 & 49 & 16 & 0 & 308 & 1370 \\
\hline \multirow{2}{*}{$\begin{array}{l}\text { Steam } \\
\text { injection }\end{array}$} & $10-125$ & GIG & 14 & 16 & 54 & 10 & 1300 & 700 \\
\hline & $10-12$ & Model & 20 & 16 & 63 & 0 & 1370 & 800 \\
\hline \multirow{2}{*}{$\begin{array}{l}\text { Oxygen } \\
\text { injection }\end{array}$} & $10-125$ & GIG & 57 & 18 & 15 & 3 & 700 & 1050 \\
\hline & $10-12$ & Model & 36 & 49 & 15 & 0 & 800 & 1250 \\
\hline
\end{tabular}

is injected into the underground cavity through a well. We assume that the pressure of the reaction zone is equal to the hydrostatic pressure. Air or oxygen is compressed in a centrifugal compressor with a mechanical efficiency of $80 \%$. The compressor is driven by an electrical motor with an efficiency of $90 \%$. The electricity is produced in a natural gas combined cycle power plant with an efficiency of $40 \%$. In the case of oxygen injection, we need to consider the production exergy of oxygen in a cryogenic air separation unit with an exergy consumption of $100 \mathrm{~kJ} / \mathrm{mol} \mathrm{O}_{2}$ [14]. The exergy of the gasification product $\left(E x_{p}\right)$ is extracted and the exhaust gas is transferred to a carbon capture and storage plant. We distinguish two different $\mathrm{CO}_{2}$ separation processes, viz. amine chemisorption and membrane separation with average

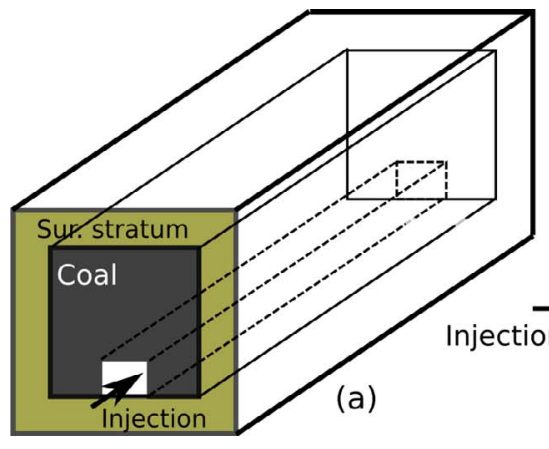

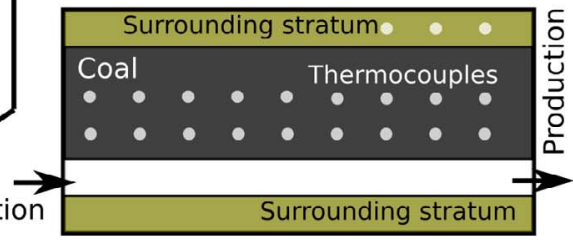

(b)
Fig. 3. (a) An schematic of the GIG field trial geo-reactor; (b) the position of the thermocouples for temperature measurements [18]. 
(a)

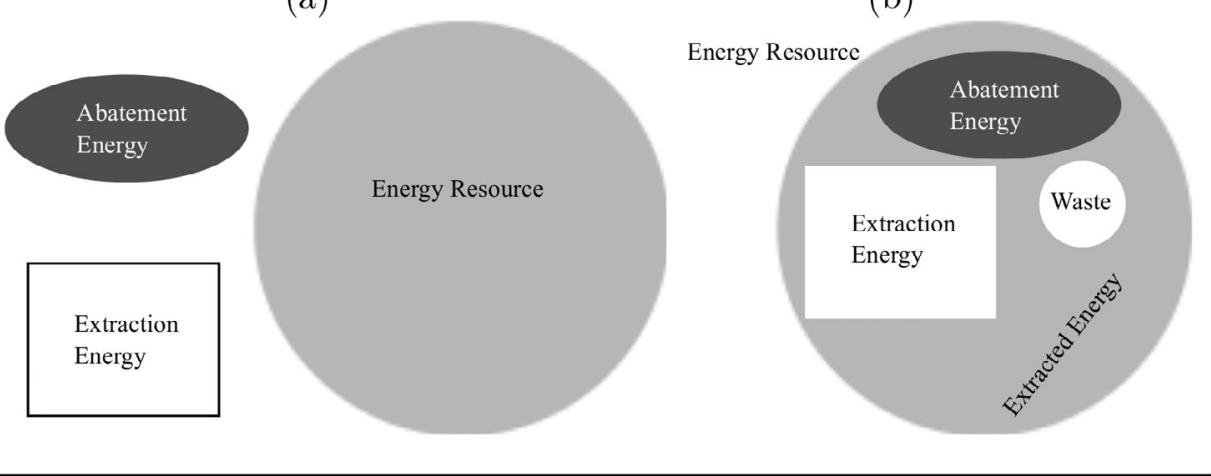

Fig. 4. (a) Energy resource, the required energy for extraction of the energy resource, and the required energy for the abatement of the environmental footprints; (b) the net magnitude of the extracted energy (gray area); (c) another view of the energy extraction process that is used for the definition of the efficiency factors.

(c)

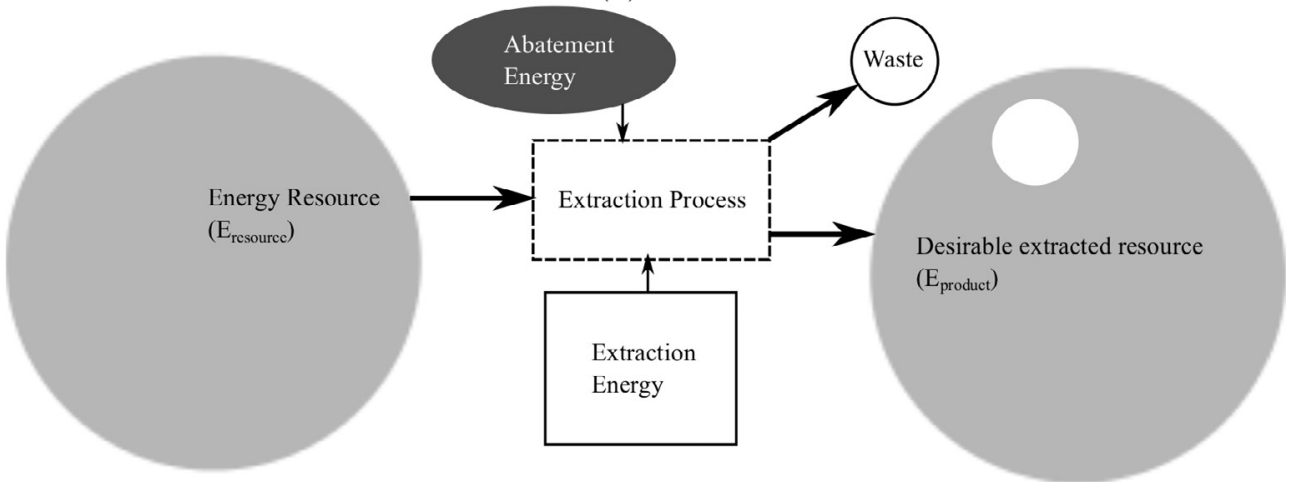

exergy requirements of $4000 \mathrm{~kJ} / \mathrm{kg} \mathrm{CO}$ and $1000 \mathrm{~kJ} / \mathrm{kg} \mathrm{CO}_{2}$, respectively. The separated $\mathrm{CO}_{2}$ is transferred to an aquifer via a $100 \mathrm{~km} \mathrm{pi-}$ peline and subsequently injected into a $1000 \mathrm{~m}$ deep aquifer, which requires an additional amount of exergy of $1000 \mathrm{~kJ} / \mathrm{kg} \mathrm{CO}_{2}$ [14].

Following Eftekhari et al. [14], the practical and zero emission recovery factors are defined by

$\mathrm{R}^{p r}=\frac{E x_{n e t}}{E x_{\text {coal }}} \quad$ and $\quad \mathrm{R}^{z e}=\frac{E x_{n e t}-E x_{C C S}}{E x_{\text {coal }}}$,

where $\mathrm{R}^{p r}$ is the practical recovery factor, $\mathrm{R}^{z e}$ is the zero emission recovery factor, $E x_{\text {coal }}\left[\mathrm{J} /\left(\mathrm{m}^{2} \mathrm{~s}\right)\right]$ is the chemical exergy of converted coal per unit surface area of coal face, and $E x_{C C S}\left[\mathrm{~J} /\left(\mathrm{m}^{2} \mathrm{~s}\right)\right]$ is the exergy requirement for the capture and storage of all the $\mathrm{CO}_{2}$ emission sources of the process shown in Fig. 5. The net recovered exergy $E x_{n e t}\left[\mathrm{~J} /\left(\mathrm{m}^{2} \mathrm{~s}\right)\right]$ is calculated by

$E x_{n e t}=E x_{p}-\left(E x_{\text {pump }}+E x_{\text {steam }}+E x_{O_{2}}+E x_{c o m p}\right)$,

where $E x_{p}\left[\mathrm{~J} /\left(\mathrm{m}^{2} \mathrm{~s}\right)\right]$ is the exergy value of the UCG product, $E x_{\text {pump }}[\mathrm{J} /$ $\left.\left(\mathrm{m}^{2} \mathrm{~s}\right)\right]$ is the exergy consumption of pump, $E x_{\text {steam }}\left[\mathrm{J} /\left(\mathrm{m}^{2} \mathrm{~s}\right)\right]$ is the exergy requirement of the steam generator, $E x_{O_{2}}\left[\mathrm{~J} /\left(\mathrm{m}^{2} \mathrm{~s}\right)\right]$ is the cumulative exergy consumption $[32,33,27]$ of oxygen flux, and $E x_{\text {comp }}$ $\left[\mathrm{J} /\left(\mathrm{m}^{2} \mathrm{~s}\right)\right]$ is the exergy consumption of the compressor.

One other factor, which can be used to compare different fossil fuels with respect to their $\mathrm{CO}_{2}$ emission is the total carbon emission per unit exergy of the final product $\left(C_{f u e l}[\mathrm{~kg} / \mathrm{J}]\right)$. Using our notations, it is calculated by

$C_{\text {fuel }}=\frac{N_{\mathrm{C}}^{t} M_{\mathrm{CO}_{2}}+\left(E x_{\text {pump }}+E x_{\text {steam }}+E x_{\mathrm{O}_{2}}+E x_{\text {comp }}\right) e_{\mathrm{CH}_{4}}}{E x_{p}}$,

where $e_{\mathrm{CH}_{4}}\left[5.5 \times 10^{-8} \mathrm{~kg} / \mathrm{J}\right]$ is the emission factor of methane (see the assumptions at the beginning of this section), $M_{\mathrm{CO}_{2}}[\mathrm{~kg} / \mathrm{mol}]$ is the molecular mass of $\mathrm{CO}_{2}$, and $N_{\mathrm{C}}^{t}\left[\mathrm{~mol} /\left(\mathrm{m}^{2} \mathrm{~s}\right)\right]$ is the molar flux of carbon in the final gaseous product, which is calculated by

$N_{\mathrm{C}}^{t}=\sum_{\alpha}\left(N_{\mathrm{CO}_{2}}^{\alpha}+N_{\mathrm{CO}}^{\alpha}+N_{\mathrm{CH}_{4}}^{\alpha}\right), \quad \alpha=$ coal, roof, rubble.

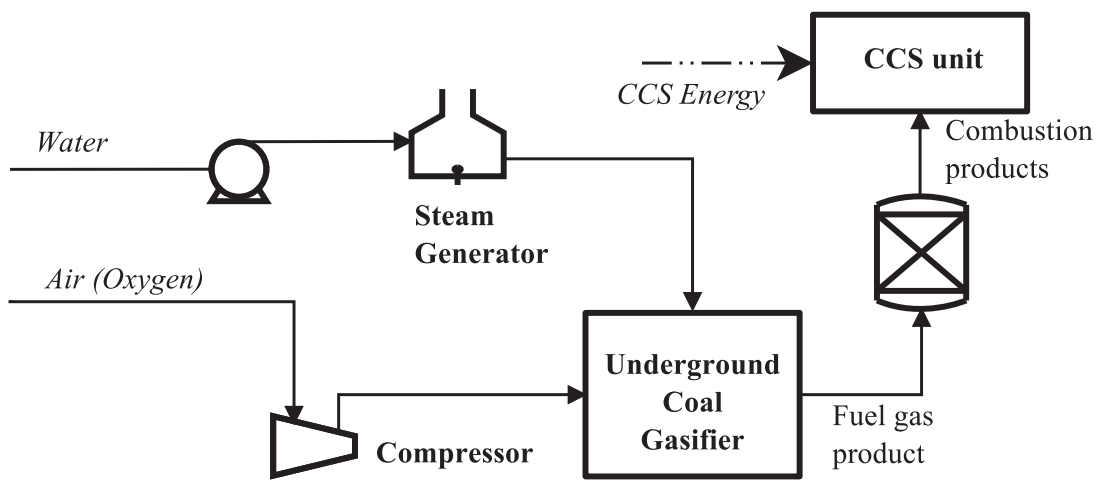

Fig. 5. Process flow diagram of the UCG process. 


\section{Results and discussion}

\subsection{Steady state results}

In [16] we showed that to have an effective alternating injection UCG process, the duration of steam and oxygen injection stages must be in the order of a few hours. e.g., 2.0-5.0 h. In a pilot scale trial, i.e., to gasify a few cubic meters of coal, it is possible to switch frequently between oxygen and steam injection. However, at the field scale, i.e., to gasify a few thousands cubic meters of coal, it is not practical to switch between oxygen and steam every few hours. In addition the high quality product of the steam stage will be mixed with the rather low quality product of the oxygen stage, which is counterproductive to our goal of producing separate products. In this subsection, we analyze the co-injection of steam and oxygen and its effect on the quality of the UCG product. We ignore the heat loss to the surrounding strata, which converts our model to steady-state. We study the effect of steam $/ \mathrm{O}_{2}$ ratio on the temperature profile and the quality of the product at low and high pressures, and use the result to perform an exergy analysis of the overall process.

\subsubsection{Steam $/ \mathrm{O}_{2}$ ratio}

We applied our extended gasification model in steady state mode to underground gasification of Barbara coal (Poland [5,20]). We consider to inject oxygen with a constant flux of $0.1 \mathrm{~mol} /\left(\mathrm{m}^{2} \mathrm{~s}\right)$ and vary the injection flux of steam between 0.05 and $0.45 \mathrm{~mol} /\left(\mathrm{m}^{2} \mathrm{~s}\right)$ to obtain a water $/ \mathrm{O}_{2}$ ratio that varies between 0.5 and 4.5. Fig. 6 shows the temperature profile on the roof, rubble, and coal faces and the average temperature of the product gas (i.e., the temperature of the gas phase in the cavity) at two different pressures, i.e., 3 bar and 80 bar. In general, the highest temperature is observed on the rubble face, where the combustible gas reacts with the injected oxygen and generates heat. The lowest temperature is observed on the coal face, where the endothermic gasification reactions occur. The temperature of the gas phase in the cavity and the temperature on the roof face are between the temperature of the coal and the rubble faces. At a low pressure ( $3 \mathrm{bar}$ ), the average temperature in the cavity is around $1700 \mathrm{~K}$ for a steam $/ \mathrm{O}_{2}$ ratio of 0.5 (see Fig. 6a), which drops linearly to $1300 \mathrm{~K}$ by increasing the steam $/ \mathrm{O}_{2}$ ratio to 2.0. At the same time, the rate of conversion of coal to combustible gases increases from $0.17 \mathrm{~m} /$ day to a maximum value of $0.20 \mathrm{~m} /$ day at a steam $/ \mathrm{O}_{2}$ ratio of 2.25 . Then, by increasing the steam $/ \mathrm{O}_{2}$ ratio from 2.0 to 4.5 , the rate at which the temperature drops slows down and the temperature linearly drops from $1300 \mathrm{~K}$ to $1200 \mathrm{~K}$, which is above the lower temperature limit of $1000 \mathrm{~K}$ to achieve practical gasification reaction rates [34]. The rate of conversion of coal starts decreasing by going above the steam $/ \mathrm{O}_{2}$ ratio of 2.25. Fig. $6 \mathrm{~b}$ shows the temperature profile in the cavity and the rate of conversion of coal as a function of the injected steam $/ \mathrm{O}_{2}$ ratio at $80 \mathrm{bar}$. Similar to the low pressure case, the temperature is high $(1600 \mathrm{~K})$ at low steam $/ \mathrm{O}_{2}$ ratio and gradually drops to a lower value of $1300 \mathrm{~K}$ by increasing the steam $/ \mathrm{O}_{2}$ ratio to 4.5. Again, we observe a maximum for the rate of coal conversion at a steam $/ \mathrm{O}_{2}$ ratio of around 2.0. Up to this steam $/ \mathrm{O}_{2}$ ratio, the temperature drops faster than above this value (see Fig. 6). As discussed in [16], the mass transfer rate from the coal surface declines with increasing pressure, which subsequently decreases the endothermic conversion of coal to a gaseous product. As a result, at high pressure, the temperature drops more slowly by increasing the steam $/ \mathrm{O}_{2}$ ratio compared to low pressure gasification.

Fig. $7 \mathrm{a}$ and $\mathrm{b}$ shows the composition of the gasification product of the co-injection of oxygen and steam in a coal layer at 3 bar and 80 bar, respectively. As to the composition of the gas at both low and high pressures, the molar composition of water in the product increases by increasing the steam $/ \mathrm{O}_{2}$ ratio, which means that the total amount of injected steam cannot be converted to a gaseous product and its conversion declines. This decline in the conversion of steam is slightly higher at higher pressure. The other observation is that at low pressure, the $\mathrm{CO}$ and $\mathrm{H}_{2}$, i.e., the combustible or valuable products, show a higher mole fraction at lower pressure while the mole fraction of $\mathrm{H}_{2}$ shows a maximum at a steam $/ \mathrm{O}_{2}$ ratio of around 1.5. By increasing steam $/ \mathrm{O}_{2}$ ratio, the mole fraction of $\mathrm{CO}$ decreases and the mole fraction of $\mathrm{CO}_{2}$ increases, which can be explained by the endothermic Boudouard-Bell reaction, i.e., Eq. (9), which shifts to the left side (production of more $\mathrm{CO}_{2}$ ) at lower temperatures (see Fig. 7a). These numbers suggest that an optimum steam $/ \mathrm{O}_{2}$ ratio can probably be found in the range between 0.5 and 1.5. The optimum value can be obtained by performing an exergy analysis (see Section 3.2). Similarly, at $80 \mathrm{bar}$ (see Fig. $7 \mathrm{~b}$ ) the optimum water $/ \mathrm{O}_{2}$ ratio can be expected to fall in the range between 0.5 and 1.8, considering the maximum mole fraction of hydrogen, which is observed at a steam $/ \mathrm{O}_{2}$ ratio of around 1.8 .

To summarize, the important practical parameters that are sensitive to the change of the steam $/ \mathrm{O}_{2}$ ratio are the rate of conversion of coal, and the mole fraction of $\mathrm{CO}$ and $\mathrm{H}_{2}$. Rationally, we are interested in high temperatures (which keeps the reaction rates high), a high steam/ $\mathrm{O}_{2}$ ratio (which can potentially convert more steam to combustible gases), a high hydrogen mole fraction (which is a fossil fuel with zero carbon emission), and a high CO mole fraction (which increases the heating value of the UCG product). We observe that we cannot find a single optimum value of steam $/ \mathrm{O}_{2}$ ratio that optimizes all the mentioned practical parameters at the same time. In the next section, we will combine all these criteria and find the optimum value of the steam/ $\mathrm{O}_{2}$ ratio by performing an exergy analysis.

\subsubsection{The pyrolysis reaction and formation of methane}

In contact with the hot gasification product in the absence of oxygen, coal with the chemical formula $\mathrm{CH}_{\bar{a}} \mathrm{O}_{\bar{b}}$, is decomposed and

(a)

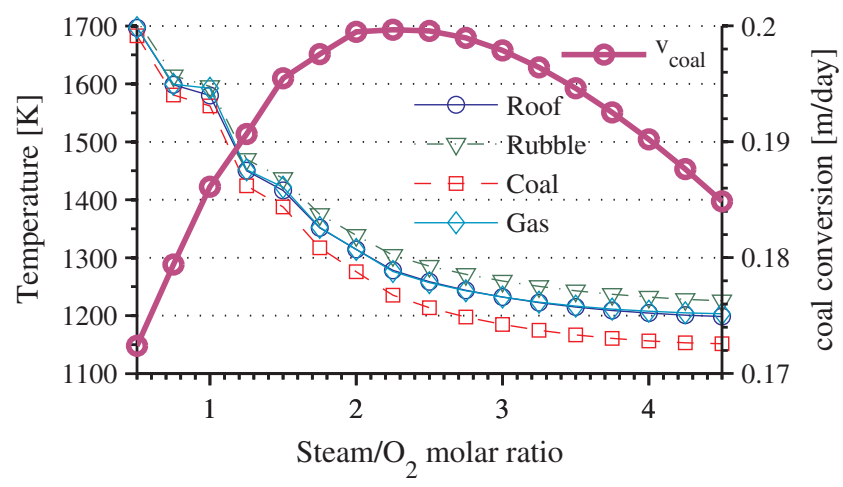

(b)

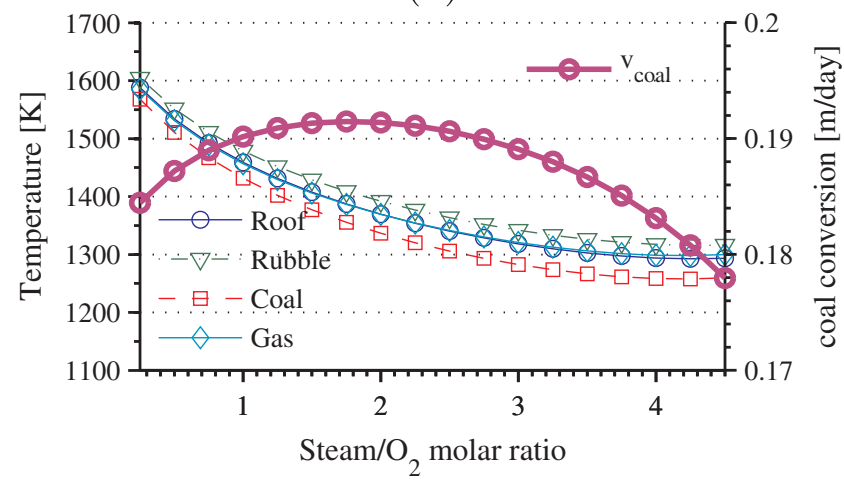

Fig. 6. Steady state temperature profile at (a) 3 bar; (b) 80 bar. The oxygen $\left(\mathrm{O}_{2}\right)$ injection rate is constant at $0.1 \mathrm{~mol} /\left(\mathrm{m}^{2} \mathrm{~s}\right)$ and the steam injection rate is altered to investigate the effect of various steam $/ \mathrm{O}_{2}$ ratios. $v_{\text {coal }}$ [m/day] shows the rate of conversion of coal, i.e., the rate by which the coal face recesses due to the conversion of coal in the combustion and gasification reactions [16]. 
(a)

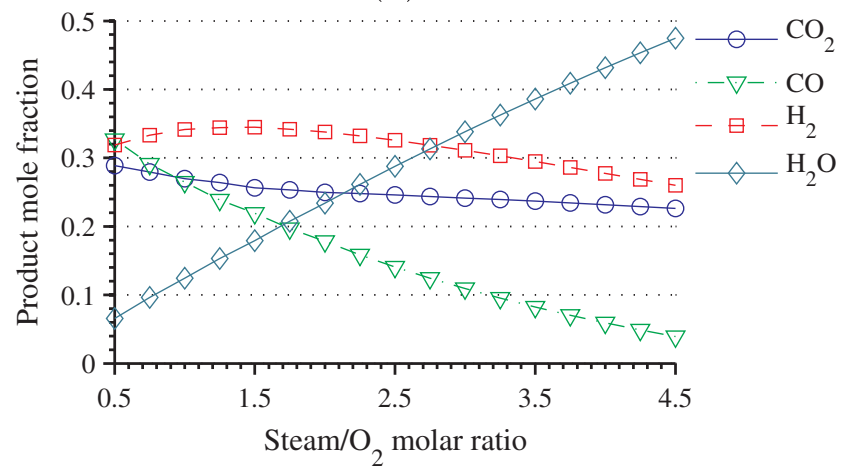

(b)

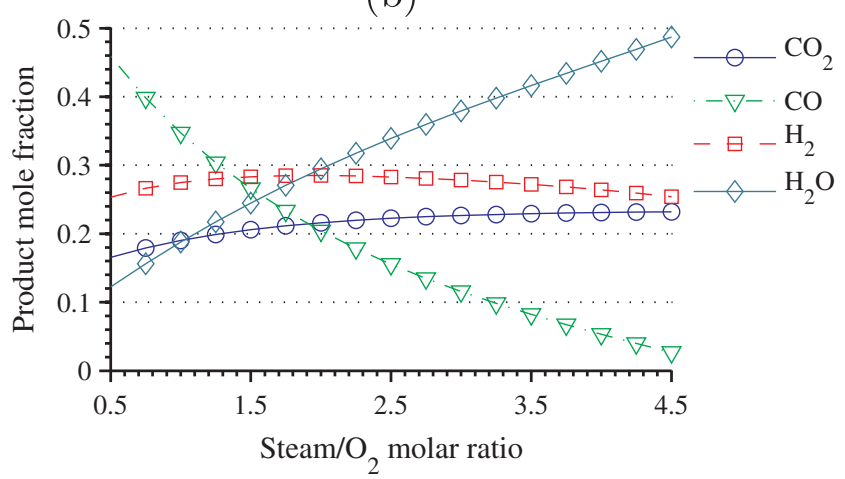

Fig. 7. Steady state composition profile as a function of water $/ \mathrm{O}_{2}$ ratio at (a) 3 bar; (b) 80 bar. The $\mathrm{O}_{2}$ injection rate is $0.1 \mathrm{~mol} /\left(\mathrm{m}^{2} \mathrm{~s}\right)$.

converted to char $\left(\mathrm{CH}_{a} \mathrm{O}_{b}\right)$ and releases gaseous components. In our model, this is represented by the following chemical reaction:

$$
\begin{aligned}
\left(N_{\mathrm{CH}_{4}}^{c}+N_{\mathrm{CO}}^{c}+N_{\mathrm{CO}_{2}}^{c}\right) \mathrm{CH}_{\bar{a}} \mathrm{O}_{\bar{b}} & \rightarrow N_{\mathrm{CO}_{2}}^{c} \mathrm{CO}_{2}+N_{\mathrm{H}_{2} \mathrm{O}}^{c} \mathrm{H}_{2} \mathrm{O}+N_{\mathrm{CO}}^{c} \mathrm{CO} \\
+ & N_{\mathrm{CH}_{4}}^{c} \mathrm{CH}_{4}+N_{\mathrm{H}_{2}}^{c} \mathrm{H}_{2},
\end{aligned}
$$

where $N_{i}^{c}\left[\mathrm{~mol} /\left(\mathrm{m}^{2} \mathrm{~s}\right)\right]$ denotes the flux of component $i$ from the coal surface. In the previous sections, we assumed that both coal and char have the same chemical formula, i.e., $\mathrm{CH}_{0.6694} \mathrm{O}_{0.1265}$. Here, to investigate the effect of the pyrolysis reaction on the final product composition, we assume that coal has a chemical formula of $\mathrm{CH}_{1.0} \mathrm{O}_{0.1265}$, i.e., it contains more hydrogen before pyrolysis. Fig. 8 shows the temperature and composition of the product gas in the cavity for the injection of $0.1 \mathrm{~mol} /\left(\mathrm{m}^{2} \mathrm{~s}\right)$ oxygen and different fluxes of water. By increasing the water to oxygen ratio from 0.25 to 4.5 , the temperature in the cavity decreases almost linearly from $1620 \mathrm{~K}$ to $950 \mathrm{~K}$, which is similar to the results of the model without the pyrolysis reaction. However, the coal conversion rate drops from $0.176 \mathrm{~m} /$ day to a minimum of $0.14 \mathrm{~m} /$ day at a water $/ \mathrm{O}_{2}$ ratio of 3.0 and then sharply increases to $0.21 \mathrm{~m} /$ day at a water $/ \mathrm{O}_{2}$ ratio of 4.5 , which is a result of the pyrolysis reaction and the formation of methane at lower temperatures. This can be observed quantitatively in Fig. 8b, which shows the composition of the produced syngas. Above the water $/ \mathrm{O}_{2}$ ratio of 2.5 , where the temperature drops below $1000{ }^{\circ} \mathrm{C}(1273 \mathrm{~K})$, methane starts to appear in the product and reaches a molar composition of $9.0 \%$ at the water $/ \mathrm{O}_{2}$ ratio of 4.5. This causes an increase in the chemical exergy of the produced syngas that reaches a value of $228 \mathrm{~kJ} / \mathrm{mol}$ (for the dried gas). The effect of this significant increase in the heating value of the produced gas on the exergy balance of the process will be discussed later. We must note that at the temperature reactions lower than $1000 \mathrm{~K}$, the gasification and pyrolysis reactions might be kinetically controlled. This will violate the chemical equilibrium assumption in our model. Therefore, for high water $/ \mathrm{O}_{2}$ ratio, the model and its results must be used with extra caution.

\subsection{Exergy analysis}

This section deals with the exergy analysis of both the steady state and dynamic cases. We follow the procedure explained in reference [14] to calculate the practical and zero emission recovery factors of the UCG process with alternating and simultaneous injection of oxygen and steam.

The effect of pressure on the average chemical exergy (see Section 3.2) of the product of the steam injection stage and the oxygen injection stage are shown in Fig. 9. The chemical exergy of the steam injection first drops from around $190 \mathrm{~kJ} / \mathrm{mol}$ at $3 \mathrm{bar}$ to around $180 \mathrm{~kJ} / \mathrm{mol}$ at $20 \mathrm{bar}$, but for the pressure above 20 bar stays almost constant at $180 \mathrm{~kJ} / \mathrm{mol}$. This behavior is in agreement with the composition of the dry product gas of the steam injection stage, that does not change by increasing the pressure above 20 bar. However, for the oxygen injection stage, the chemical exergy drops from around $170 \mathrm{~kJ} / \mathrm{mol}$ at $20 \mathrm{bar}$ to around $150 \mathrm{~kJ} / \mathrm{mol}$ at $80 \mathrm{bar}$. It can be explained by the Boudouard-Bell reaction, i.e.,

$\mathrm{C}+\mathrm{CO}_{2} \rightleftharpoons 2 \mathrm{CO}$,

which shifts to the left side at high pressures and produces more $\mathrm{CO}_{2}$ and decreases the amount of $\mathrm{CO}$ in the final product.

To summarize, by increasing the UCG pressure, the quality and flow rate of the gaseous product (rate of conversion of coal) decline, which suggests that high pressure is not a favorable condition for underground coal gasification. We will discuss this observation quantitatively in Section 3.2.

We showed that the optimum condition is the one that maximizes the rate of conversion of coal and steam, the mole fractions of hydrogen and carbon monoxide, and minimizes the carbon content per unit exergy of the final gaseous product. We previously showed that we cannot find a single set of process parameters that satisfy simultaneously all the mentioned conditions. Therefore, we use the exergy analysis to find the optimum process parameters.

(a)

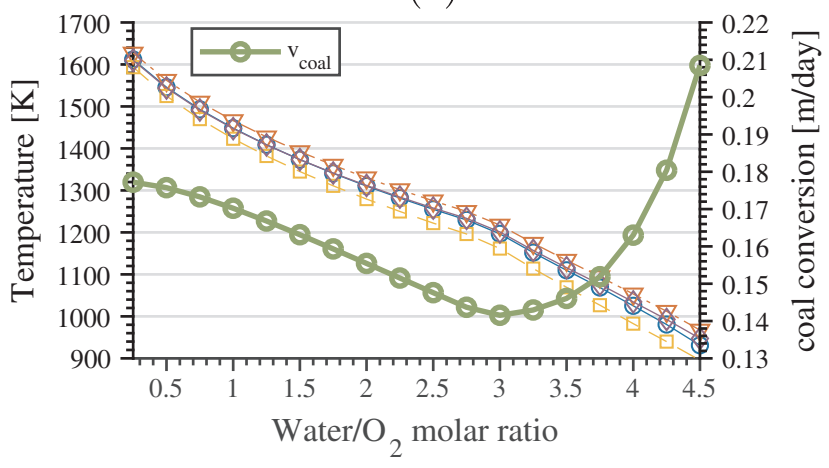

(b)

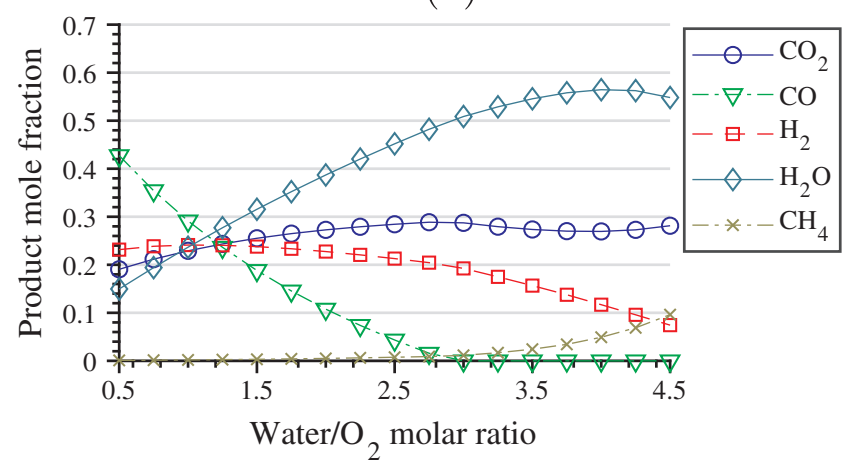

Fig. 8. Steady state temperature and composition of the product as a function of water $/ \mathrm{O}_{2}$ ratio at $80 \mathrm{bar}$, for the injection of water and $0.1 \mathrm{~mol} /\left(\mathrm{m}^{2} \mathrm{~s}\right)$ oxygen. 


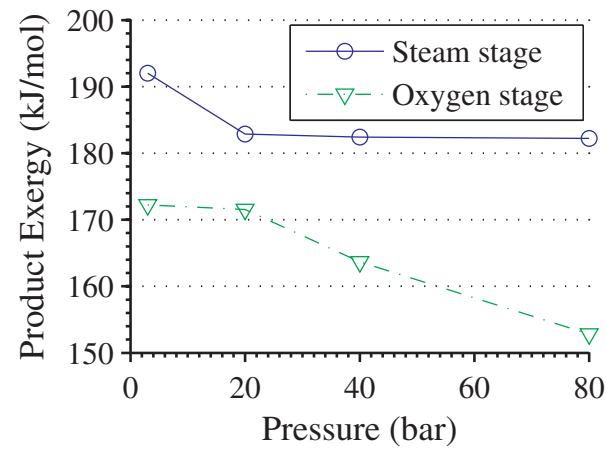

Fig. 9. The average chemical exergy of the dry gas product in the steam injection stage (o markers) and in the oxygen injection stage ( $\nabla$ markers) for the same conditions as of the GIG field trial but at different pressures. The GIG field trial was carried out at atmospheric pressure.

Fig. 10 shows the values of practical and zero-emission recovery factors for the simulation results of the GIG field trial at different pressures. At $3 \mathrm{bar}$, the practical recovery factor for an alternating injection of oxygen and steam is equal to $39 \%$, which means that a net amount of $39 \%$ of the converted coal is extracted in the form of a gaseous product with a net emission factor of $0.11 \mathrm{~kg} \mathrm{CO} / \mathrm{MJ}$. This emission factor is only two times higher than the emission factor of methane, which is the cleanest fossil fuel in terms of $\mathrm{CO}_{2}$ emission. However, the zero-emission recovery factor is only $12 \%$ for membrane $\mathrm{CO}_{2}$ separation technology (which is not yet proven for large scale applications [35]). The zero emission recovery factor drops to $-28 \%$ for amine separation of $\mathrm{CO}_{2}$ (current state of technology), which shows that a fully zero emission UCG process with alternating injection of oxygen and steam with the present state of technology is not viable. The recovery factors decrease rapidly with increasing pressure. For pressures above 20 bar, the practical recovery factor becomes negative. It means that with the current state of technology, the UCG process with alternating injection of oxygen and steam is not a practical choice for high pressure conversion of deep coal layers. However, for low pressure gasification, the practical recovery factor is acceptable although the zero emission UCG process with the current state of technology is not practical for the alternating injection process.

Fig. 11 shows the result of exergy analysis obtained from applying our extended gasification model to low and high pressure underground gasification of Barbara coal. The values of the practical recovery factor, zero emission recovery factor with amine separation of $\mathrm{CO}_{2}$, and zeroemission recovery factor for membrane separation of $\mathrm{CO}_{2}$, and the $\mathrm{CO}_{2}$ emission per unit exergy of product are shown in Fig. 11a for UCG at 3 bar (low pressure) and in Fig. 11b for UCG at 80 bar (high pressure). At low pressure (Fig. 11a) the practical recovery factor is $41 \%$ at a steam $/ \mathrm{O}_{2}$ ratio of 0.5 and gradually increases with increasing steam $/ \mathrm{O}_{2}$ ratio to reach a maximum value of $45 \%$ at a steam $/ \mathrm{O}_{2}$ ratio of 1.5 . At the same time, the value of $C_{\text {fuel }}$ (total carbon emission per unit exergy of product) decreases from $0.17 \mathrm{~kg} \mathrm{CO} / \mathrm{MJ}$ at a steam $/ \mathrm{O}_{2}$ ratio of 0.5 to 0.156 at a steam $/ \mathrm{O}_{2}$ ratio of 1.5 , which is close to its minimum value of 0.155 at a steam $/ \mathrm{O}_{2}$ ratio of 2.0. The recovery factor follows a decreasing trend above a steam $/ \mathrm{O}_{2}$ ratio of 1.5 . By applying an amine capturing technique to all the $\mathrm{CO}_{2}$ emission sources the process can become a zero-emission process. However, the value of zero-emission recovery factor ( $\mathrm{R}^{z e, a m i n e}$ ) showed in Fig. 11a is always negative, which suggests that the zero-emission UCG process with the current state of technology is not yet practical. Using emerging technologies such as membrane separation can improve the recovery factor, as shown in Fig. 11a by $\mathrm{R}^{z e, m e m b r a n e}$. The zero-emission recovery factor reaches a maximum value of $24 \%$ at a steam $/ \mathrm{O}_{2}$ ratio of 1.5 , which means that only $24 \%$ of the converted coal can be extracted. The economical feasibility of the process with this recovery factor is outside the scope of this work. Fig. 11b shows the exergy analysis result at a pressure of
80 bar (deep coal layer). We use a lower limit of 0.25 for the steam $/ \mathrm{O}_{2}$ ratio for practical purposes, because below this value the temperature in the cavity becomes too high (see Fig. 6b). At a steam $/ \mathrm{O}_{2}$ ratio of 0.25 , the practical recovery attains its maximum value of $46 \%$, which gradually decreases to a value of $12 \%$ by increasing steam $/ \mathrm{O}_{2}$ ratio to 4.5, while the total $\mathrm{CO}_{2}$ emission per unit product exergy increases from a minimum value of $0.16 \mathrm{~kg} / \mathrm{MJ}$ to $0.19 \mathrm{~kg} / \mathrm{MJ}$. Again, similar to the low pressure case in Fig. 11a, the zero emission recovery factor, using the state of the art $\mathrm{CO}_{2}$ capturing technology (amine separation), is negative for the whole range of steam $/ \mathrm{O}_{2}$ ratios, which shows that the zero-emission process is not viable. However, by using membrane separation of $\mathrm{CO}_{2}$, the zero-emission recovery factor can reach a maximum value of $26 \%$ at a steam $/ \mathrm{O}_{2}$ ratio of 0.25 .

In the simulation of the mixed injection of steam $/ \mathrm{O}_{2}$ (Fig. 11), we assumed that only a fraction of heat is lost during steam injection. However, in practice, for long injection wells at low injection rates, up to $90 \%$ of heat can be lost, which causes the condensation of steam [31]. To avoid this heat loss, we can inject liquid water (or allow underground water influx into the cavity by adjusting the pressure) and vaporize it in the rubble zone by using the heat of reaction of the injected oxygen with combustible gases. In our model, this can be implemented by assigning the heat of vaporization of water to the parameter $\Delta h_{\mathrm{H}_{2} \mathrm{O}}^{\text {va }}[\mathrm{J} / \mathrm{mol}]$ in the energy balance of the rubble zone (see [16]). Fig. 12 shows the exergy analysis results for the UCG with the coinjection of water and oxygen. The general behavior of the recovery factors and $\mathrm{CO}_{2}$ emission is similar to the co-injection of steam and oxygen (Fig. 11). There are however a few differences in the optimum values of recovery factors and the value of a water $/ \mathrm{O}_{2}$ ratio that maximizes the recovery factor and minimizes the total $\mathrm{CO}_{2}$ emission per unit exergy of product. At $3 \mathrm{bar}$, as shown in Fig. 12a, the maximum practical recovery factor is equal to $50 \%$ ( $45 \%$ for the steam injection) and the total $\mathrm{CO}_{2}$ emission per unit exergy of product is equal to $0.156 \mathrm{~kg} / \mathrm{MJ}$ (same value for the steam injection) at a water $/ \mathrm{O}_{2}$ ratio of 1.25 (steam $/ \mathrm{O}_{2}$ ratio of 1.5 ). Here we ignore any practical complications of gravity segregation. The $5 \%$ higher practical recovery factor for the water injection compared to steam injection is a direct result of avoiding the heat loss that occurs during the injection of steam. On the downside, the optimum value is reached at a lower water $/ \mathrm{O}_{2}$ ratio, which means that a lower amount of water is converted to combustible products. Also, the rate of conversion of the coal layer for the water injection case (not shown in the figures) is $1 \mathrm{~cm} /$ day lower than the steam injection case (Fig. 6). Unlike the steam injection case, the zeroemission recovery factor with the state of the art $\mathrm{CO}_{2}$ capturing technology (amine chemisorption) is not always negative and indeed it reaches a maximum value of $1.5 \%$ at a water $/ \mathrm{O}_{2}$ ratio of 1.25 , which is however too low to make the zero-emission process a practical option. By using a membrane separation process for $\mathrm{CO}_{2}$ capturing, the zero emission recovery factor can be improved up to a maximum value of $30 \%$ at a water $/ \mathrm{O}_{2}$ ratio of 1.25 . Fig. $12 \mathrm{~b}$ shows the exergy analysis

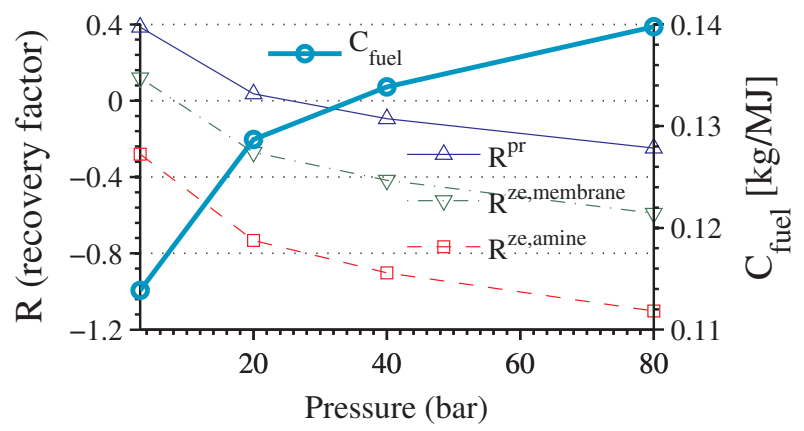

Fig. 10. Recovery factors and $\mathrm{CO}_{2}$ emission of UCG with alternating injection of oxygen and steam at different pressures; the simulation results of [16] are used for the calculation of practical and zero-emission (amine chemisorption, membrane capturing) recovery factors and $\mathrm{CO}_{2}$ emission per unit exergy of products. 
(a)

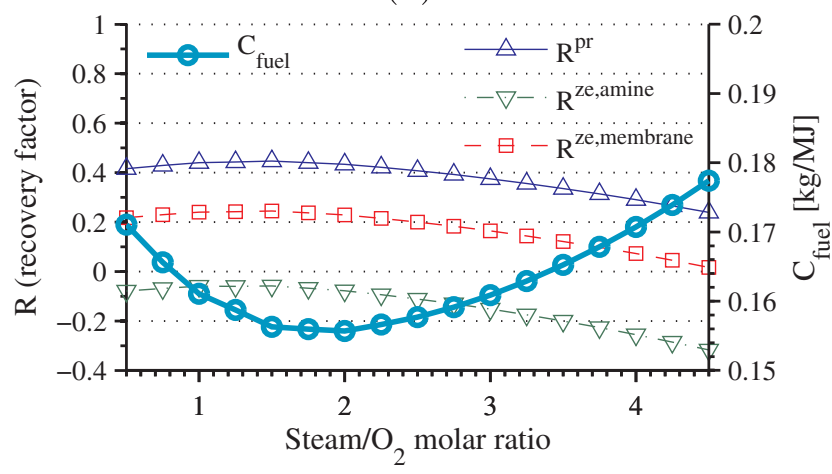

(b)

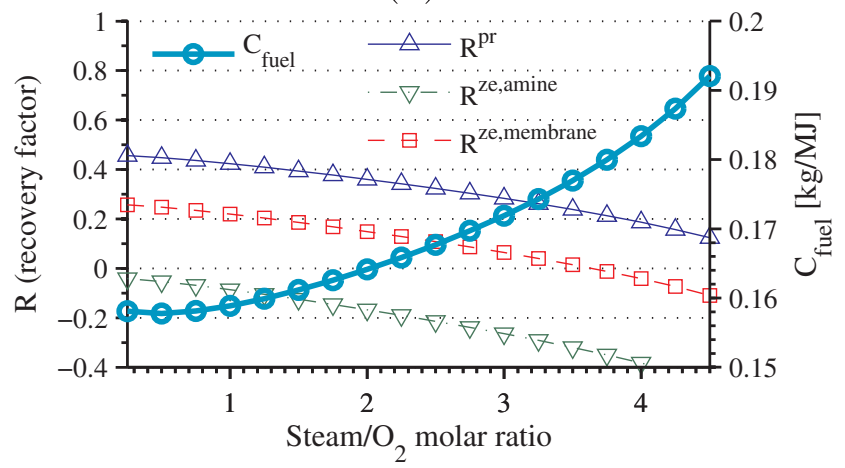

Fig. 11. Exergy analysis of channel gasification of thin coal for injection of a steam $/ \mathrm{O}_{2}$ mixture with various compositions at (a) 3 bar and (b) 80 bar; Practical and zero emission recovery factors and product gas $\mathrm{CO}_{2}$ emission per unit exergy of product are shown.

(a)

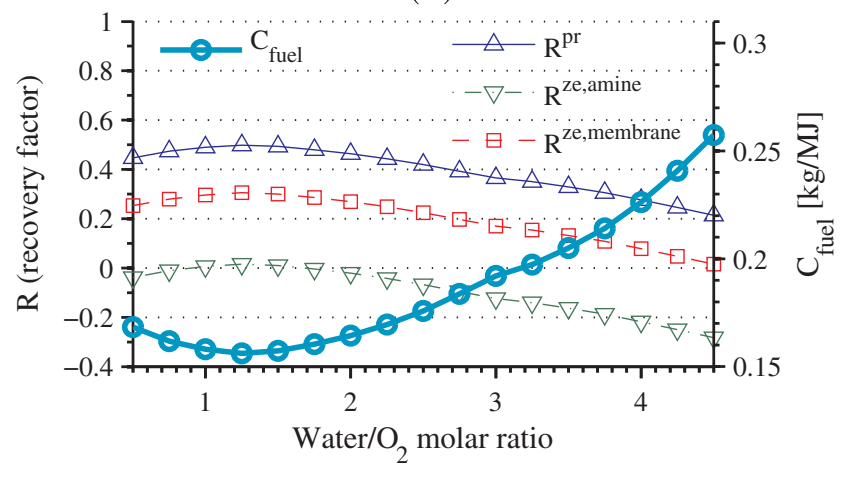

(b)

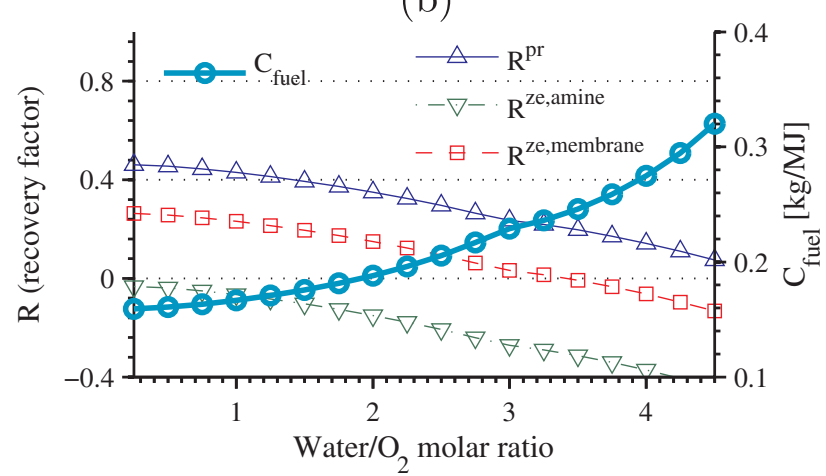

Fig. 12. Exergy analysis of channel gasification of thin coal for injection of a water $/ \mathrm{O}_{2}$ mixture with various compositions at (a) 3 bar and (b) 80 bar; Practical and zero emission recovery factors and product gas $\mathrm{CO}_{2}$ emission per unit exergy of product are shown.

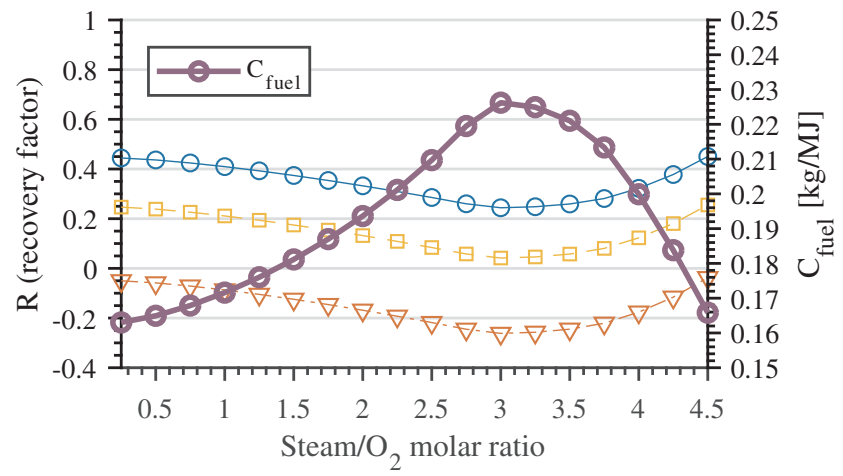

Fig. 13. Exergy analysis of the process at 80 bar for the injection of oxygen and water when the pyrolysis reaction and methane formation is included in the model; the thin lines show the practical (circle markers), zero-emission with membrane $\mathrm{CO}_{2}$ capture (square markers), and zero-emission with amine $\mathrm{CO}_{2}$ capture (triangle markers) recovery factors, respectively. The thick line shows the carbon content of the produced syngas.

result and total $\mathrm{CO}_{2}$ emission per unit exergy of product for deep UCG at 80 bar with the co-injection of water and oxygen. Compared to the high pressure UCG with steam injection (Fig. 11b), the maximum recovery factor is $46 \%$ (same value for steam injection, see Fig. 11b) and the minimum $\mathrm{CO}_{2}$ emission per unit exergy is $0.16 \mathrm{~kg} / \mathrm{MJ}$ (the same value as for steam injection) both at a water $/ \mathrm{O}_{2}$ ratio of 0.25 . However, the rate of conversion of coal is around $1 \mathrm{~cm} /$ day lower than the steam injection case (Fig. 6). The other difference with the steam injection case is that by increasing the water $/ \mathrm{O}_{2}$ ratio, the value of $\mathrm{CO}_{2}$ emission increases much faster for the water injection case, whereas it increases from its minimum value at a water $/ \mathrm{O}_{2}$ ratio of 0.25 to a value of 0.32 at a water $/ \mathrm{O}_{2}$ ratio of 4.5. Similar to the high pressure UCG with steam injection, the zero-emission recovery factor with amine capturing technique is not viable with a negative recovery factor for the whole range of water $/ \mathrm{O}_{2}$ ratios. However, the zero-emission recovery factor can be increased up to $26 \%$ by using a membrane $\mathrm{CO}_{2}$ capturing method. The exergy analysis results are summarized in the conclusions.

Fig. 13 shows the effect of the pyrolysis reaction and the formation of methane on the exergy balance of the process for the injection of water and oxygen at 80 bar. The practical recovery factor gradually decreases from $44 \%$ at the water $/ \mathrm{O}_{2}$ ratio of 0.25 to a minimum value of $24 \%$ at the water $/ \mathrm{O}_{2}$ ratio of 3.0 , which is similar to the behavior observed in the absence of the pyrolysis reaction. However, from this point, the recovery factor increases to a value of $45 \%$ at the water $/ \mathrm{O}_{2}$ ratio of 4.5. This behavior can be explained by the higher heating value of the syngas due to the formation of methane. We can also observe that the carbon emission factor of the produced syngas, that first increases from $0.16 \mathrm{~kg} / \mathrm{MJ}$ to $0.22 \mathrm{~kg} / \mathrm{MJ}$ by increasing the water $/ \mathrm{O}_{2}$ ratio from 0.25 to 3.0 , starts decreasing again to $0.16 \mathrm{~kg} / \mathrm{MJ}$ at the water $/ \mathrm{O}_{2}$ ratio of 4.5 , which is due to the higher methane and lower carbon monoxide content in the syngas (see Fig. 8b). The lower carbon content of the produced syngas causes the zero-emission recovery factor (membrane capture) to increase from a minimum value of $4 \%$ to $25 \%$ at a water $/ \mathrm{O}_{2}$ ratio of 4.5. If the gasification and pyrolysis reactions are not kinetically controlled at this relatively high water $/ \mathrm{O}_{2}$ ratio (see the coal face temperature in Fig. 8a), this feed composition offers the highest recovery factor, the lowest product emission factor, and the highest conversion rate of coal. Therefore, the water $/ \mathrm{O}_{2}$ ratio of 4.5 can be considered as the optimum feed composition for the high pressure gasification of thin deep coal seams. The zero emission recovery factor with the state of the art amine chemisorption technology, unfortunately, remains negative, indicating that the zero-emission gasification of deep thin coal at high pressure is not exergetically viable with the current state of technology, even though it can be realized by using a more efficient $\mathrm{CO}_{2}$ capture process, e.g., membrane separation. 


\section{Conclusions}

This study investigated whether it is possible to couple the underground coal gasification with carbon capture and storage to utilize the unmineable deep thin coal resources with a reduced carbon footprint. We investigated the effect of UCG and CCS process parameters on the feasibility of the coupled UCG-CCS process, and found the optimum values that maximize the recovery factor of coal and minimize the carbon footprint of the process.

- The alternating injection of oxygen and steam is only practical for low pressure UCG, i.e., shallow coal layers, with a recovery factor of around $40 \%$. The total $\mathrm{CO}_{2}$ emission per unit exergy of the final product is only twice as large as the emission factor of methane. The zero emission recovery of coal with alternating injection of oxygen and steam is not practical with the current state of technology.

- The conversion of coal with the co-injection of steam (or water) and oxygen is a more attractive option compared to the alternating injection. The practical recovery factor is around $50 \%$, which is $10 \%$ higher than the alternating injection process. However, the total $\mathrm{CO}_{2}$ emission per unit exergy of product is $30 \%$ higher than the alternating injection scenario.

- Low pressure is the favorable condition for UCG, with the possibility of conversion of larger amounts of water to combustible gases, with a practical recovery factor of $39 \%$ for the alternating injection of oxygen/steam and $46 \%$ for the injection of an oxygen/steam mixture

- With the current state of technology, zero emission UCG (for the process that is suggested in this work) is not a practical option with a recovery factor which is negative or very low, i.e., less than $2 \%$ of the coal energy can be recovered.

- Exergy analysis suggests that the development of a less energy intensive $\mathrm{CO}_{2}$ capturing methods, e.g., membrane separation, gives a positive recovery factor of $26 \%$. However, the economic feasibility of those methods are outside the scope of this work.

- In UCG with the co-injection of steam or water and oxygen, from a practical point of view, the injection of water, if we disregard the possible technical complications ensuing from gravity segregation of water and gaseous substances, is the preferred technique with a $5 \%$ higher recovery factor, as it avoids the high heat loss during the steam injection.

- The formation of methane in the pyrolysis reaction of coal increases the rate of conversion of coal and the heating value of the produced syngas and consequently increases the recovery factor if the process for a feed stream with high water to oxygen ratio (higher than 3.0).

\section{Acknowledgment}

The work presented in the paper has been performed in the framework of the HUGE project (Hydrogen Oriented Underground Coal Gasification for Europe). The authors would like to thank Dr. Diederik van Batenburg for his comments on the original model. The original idea of this paper comes from the late Dr. Jan Rogut, who unfortunately passed away during the preparation of this paper. We also would like to thank the three anonymous reviewer for their valuable comments.

\section{References}

[1] International Energy Agency. Coal information: overview. Tech rep; 2017. URL < http://www.iea.org/statistics/topics/coal/ >

[2] Baufumé S, Hake J-F, Linssen J, Markewitz P. Carbon capture and storage: a possible bridge to a future hydrogen infrastructure for Germany? Int J Hydrogen
Energy 2011;36(15):8809-21.

[3] Friedmann SJ, Upadhye R, Kong F-M. Prospects for underground coal gasification in carbon-constrained world. Energy Proc 2009;1(1):4551-7.

[4] Couch G. Underground coal gasification. London: IEA clean coal centre, International Energy Agency.

[5] Białecka B. Estimation of coal reserves for ucg in the upper Silesian coal basin, Poland. Nat Resources Res 2008;17(1):21-8.

[6] Yang D, Koukouzas N, Green M, Sheng Y. Recent development on underground coal gasification and subsequent $\mathrm{CO}_{2}$ storage. J Energy Inst 2016;89(4):469-84.

[7] Prabu V, Jayanti S. Integration of underground coal gasification with a solid oxide fuel cell system for clean coal utilization. Int J Hydrogen Energy 2012;37(2):1677-88.

[8] Thorsness C, Britten J. Lawrence livermore national laboratory underground coal gasification project. Tech rep. CA (USA): Lawrence Livermore National Lab.; 1989.

[9] Nakaten N, Schlüter R, Azzam R, Kempka T. Development of a techno-economic model for dynamic calculation of cost of electricity, energy demand and $\mathrm{CO}_{2}$ emissions of an integrated UCG-CCS process. Energy 2014;66:779-90.

[10] Nakaten N, Kötting P, Azzam R, Kempka T. Underground coal gasification and $\mathrm{CO}_{2}$ storage support bulgaria's low carbon energy supply. Energy Proc 2013;40:212-21.

[11] Nakaten N, Azzam R, Kempka T. Sensitivity analysis on UCG-CCS economics. Int J Greenhouse Gas Contr 2014;26:51-60.

[12] Blinderman MS, Anderson B. Underground coal gasification for power generation: high efficiency and $\mathrm{CO}_{2}$-emissions. In: ASME 2004 power conference, American Society of Mechanical Engineers; 2004. p. 473-9.

[13] Blinderman M, Saulov D, Klimenko A. Exergy optimisation of reverse combustion linking in underground coal gasification. J Energy Inst 2008;81(1):7-13.

[14] Eftekhari AA, Van Der Kooi H, Bruining H. Exergy analysis of underground coal gasification with simultaneous storage of carbon dioxide. Energy 2012;45(1):729-45.

[15] Bicer Y, Dincer I. Energy and exergy analyses of an integrated underground coa gasification with SOFC fuel cell system for multigeneration including hydrogen production. Int J Hydrogen Energy 2015;40(39):13323-37.

[16] Eftekhari AA, Wolf KH, Rogut J, Bruining H. Mathematical modeling of alternating injection of oxygen and steam in underground coal gasification. Int J Coal Geol 2015;150:154-65.

[17] Yang L, Zhang X, Liu S, Yu L, Zhang W. Field test of large-scale hydrogen manufacturing from underground coal gasification (UCG). Int J Hydrogen Energy 2008;33(4):1275-85.

[18] Stanczyk K, Smolinski A, Kapusta K, Wiatowski M, Swiadrowski J, Kotyrba A, et al Dynamic experimental simulation of hydrogen oriented underground gasification of lignite. Fuel 2010;89(11):3307-14.

[19] Stanczyk K, Kapusta K, Wiatowski M, Swiadrowski J, Smolinski A, Rogut J, et al. Experimental simulation of hard coal underground gasification for hydrogen production. Fuel.

[20] Stańczyk K, Howaniec N, Smoliński A, Świa drowski J, Kapusta K, Wiatowski M, et al. Gasification of lignite and hard coal with air and oxygen enriched air in a pilot scale ex situ reactor for underground gasification. Fuel 2011;90(5):1953-62.

[21] Laciak M, Kačur J, Kostúr K. The verification of thermodynamic model for UCG process. 2016 17th International Carpathian control conference (ICCC). IEEE; 2016 p. 424-8.

[22] Laciak M, Kostúr K, Durdán M, Kačur J, Flegner P. The analysis of the underground coal gasification in experimental equipment. Energy 2016;114:332-43.

[23] Uppal AA, Bhatti AI, Aamir E, Samar R, Khan SA. Control oriented modeling and optimization of one dimensional packed bed model of underground coal gasification. J Process Contr 2014;24(1):269-77.

[24] Uppal AA, Bhatti AI, Aamir E, Samar R, Khan SA. Optimization and control of one dimensional packed bed model of underground coal gasification. J Process Contr 2015;35:11-20.

[25] Hettema M, Wolf KA, De Pater C. The influence of steam pressure on thermal spalling of sedimentary rock: theory and experiments. Int J Rock Mech Min Sci 1998;35(1):3-15.

[26] Wolf K-H, Bruining H. Modelling the interaction between underground coal fires and their roof rocks. Fuel 2007;86(17):2761-77.

[27] Szargut J, Morris D, Steward F. Energy analysis of thermal, chemical, and metallurgical processes. New York (NY): Hemisphere Publishing; 1988.

[28] Sciubba E, Wall G. A brief commented history of exergy from the beginnings to 2004. Int J Thermodyn 2007;10(1):1-26.

[29] Tsatsaronis G. Comments on the paper 'a brief commented history of exergy from the beginnings to 2004'. Int J Thermodyn 2007;10(4):187-92.

[30] Bejan A, Tsatsaronis G. Thermal design and optimization. John Wiley \& Sons; 1996.

[31] Ramey Jr H. Wellbore heat transmission. J Petrol Technol 1962;14(4):427-35.

[32] Szargut J. Analysis of cumulative exergy consumption. Int J Energy Res 1987;11(4):541-7.

[33] Szargut J, Morris D. Cumulative exergy consumption and cumulative degree of perfection of chemical processes. Int J Energy Res 1987;11(2):245-61.

[34] Van Batenburg D, Biezen E, Bruining J. A new channel model for underground gasification of thin, deep coal seams. In Situ 1994;18. 419-419.

[35] Brunetti A, Scura F, Barbieri G, Drioli E. Membrane technologies for $\mathrm{CO}_{2}$ separation. J Membr Sci 2010;359(1-2):115-25. 